\title{
Synthesis, Urease Inhibition, Antioxidant, Antibacterial, and Molecular Docking Studies of 1,3,4-Oxadiazole Derivatives
}

\author{
Muhammad Hanif, ${ }^{1}$ Khurram Shoaib, ${ }^{2}$ Muhammad Saleem, ${ }^{1}$ \\ Nasim Hasan Rama, ${ }^{1}$ Sumera Zaib, ${ }^{2}$ and Jamshed Iqbal ${ }^{2}$ \\ ${ }^{1}$ Department of Chemistry, Quaid-i-Azam University, Islamabad 45320, Pakistan \\ ${ }^{2}$ Department of Pharmaceutical Sciences, COMSATS Institute of Information Technology, Abbottabad 22060, Pakistan
}

Correspondence should be addressed to Nasim Hasan Rama, nhrama@qau.edu.pk and Jamshed Iqbal, drjamshed@ciit.net.pk

Received 6 April 2012; Accepted 24 June 2012

Academic Editors: G. M. Campo and R. Villalobos-Molina

Copyright (c) 2012 Muhammad Hanif et al. This is an open access article distributed under the Creative Commons Attribution License, which permits unrestricted use, distribution, and reproduction in any medium, provided the original work is properly cited.

\begin{abstract}
A series of eighteen 1,3,4-oxadiazole derivatives have been synthesized by treating aromatic acid hydrazides with carbon disulfide in ethanolic potassium hydroxide yielding potassium salts of 1,3,4-oxadiazoles. Upon neutralization with $1 \mathrm{~N}$ hydrochloric acid yielded crude crystals of 1,3,4-oxadiazoles, which were purified by recrystallization in boiling methanol. The synthesized 1,3,4oxadiazoles derivatives were evaluated in vitro for their urease inhibitory activities, most of the investigated compounds were potent inhibitors of Jack bean urease. The molecular docking studies were performed by docking them into the crystal structure of Jack bean urease to observe the mode of interaction of synthesized compounds. The synthesized compounds were also tested for antibacterial and antioxidant activities and some derivatives exhibited very promising results.
\end{abstract}

\section{Introduction}

Urease (urea amidohydrolase; E.C. 3.5.1.5) is a nickel containing enzyme that catalyzes the hydrolysis of urea to the formation of ammonia and carbon dioxide [1]. It plays a pivotal role in nitrogen metabolism of plants during the germination process [2]. A variety of ureases have been isolated from bacteria, algae, fungi, and plants [1-3]. Irrespective of structural differences of plant and microbial originated urease, it follows same catalysis pattern. It is mainly because of similar sequence of amino acids and presence of $\mathrm{Ni}^{+2}$ ions in active site of this multimeric enzyme which indicates emergence from a common ancestry $[2,4-6]$.

The primary physiological role of urease is to provide nitrogen for organisms in the form of ammonia for their growth. However, high urease activity is responsible for release of abnormally large amounts of ammonia into atmosphere which may lead to environmental and economic problems $[1,2]$ Human and animal pathogenicity of hepatic encephalopathy, hepatic coma urolithiasis, gastric and peptic ulcers, pyelonephritis, and urinary catheter encrustation are caused by ammonia produced by ureases $[1,2,7,8]$. The urease activity of Helicobacter pylori plays an important role in the pathogenesis of gastric and peptic ulcer [2]. Therefore, urease inhibitors have the potential to be used as anti-ulcer drugs. For the said infections caused by the bacterial ureases, more effective and potent compounds are required with a whole new level of safety and specificity.

Urease has diverse functions and its inhibition has received special attention over the past few years and many antiurease agents have been reported. Among these are hydroxamic acid derivatives [9], hydroxyurea [10], hydroxamic acids [11], phosphorodiamidates [12, 13], imidazoles such as rabeprazole, [14] lansoprazole, [15] omeprazole, [16] quinines, [17] thiol-compounds, and [18] plaunotol and its thiourea derivatives [19]. Very recently we have investigated schiff base derivatives, which were most active inhibitors of Jack bean urease [20]. Through molecular modeling simulations and high-throughput virtual screening new derivatives of coumarin and triazoles were also found as urease inhibitors [21].

In the current paper, we present the synthesis of 1,3,4oxadiazoles derivatives and their evaluation for inhibitory activity against Jack bean urease. It is notable that most of 
the compounds were more potent inhibitors of the enzyme as compared to standard inhibitor (thiourea). One of the compounds $(\mathbf{4 j})$ has potent urease inhibitory activity with $\mathrm{IC}_{50}$ value of $1.15 \mu \mathrm{M}$, which is 20 -fold more active than the standard. Molecular docking study is also carried out to gain an understanding of urease inhibitory activity of 1,3,4oxadiazoles derivatives. Newly synthesized compounds were also investigated on pathogenic bacterial strains and it was observed that most of the compounds also exhibited potent antibacterial activities.

\section{Experimental}

2.1. Synthesis. All the common solvents and chemicals were of analytical grade or dry distilled. Reaction progress was determined by thin layer chromatography (TLC) analysis and $R_{f}$ values were determined by employing precoated silica gel aluminium plates, Kieslgel $60 \mathrm{~F}_{254}$ from Merck (Germany), using petroleum ether: ethyl acetate $(8: 2)$ as an eluent and TLC was visualized under UV lamp. Melting points were determined on a Stuart melting point apparatus (SMP3) and are uncorrected. The IR spectra were recorded on Bruker Optics Alpha FT-IR spectrophotometer. Proton nuclear magnetic resonance $\left({ }^{1} \mathrm{H}\right.$ NMR) spectra were recorded on a Bruker Avance $300 \mathrm{MHz}$ spectrometer with TMS as an internal standard. Chemical shift are reported as $\delta$ values (ppm) downfield from internal tetramethylsilane of the indicated organic solution. Peak multiplicities are expressed as follows: s, singlet; $d$, doublet; $t$, triplet; q, quartet; $\mathrm{dt}$, doublet of triplets. Coupling constants ( $J$ values) are given in hertz $(\mathrm{Hz})$. Mass spectra were recorded on Agilent Technologies $6890 \mathrm{~N}$ gas chromatograph and an inert mass selective detector 5973 mass spectrometer. The elemental analysis was performed on Leco CHNS-932 Elemental Analyzer, Leco Corporation (USA). Abbreviations are used as follows: DMSO- $d_{6}$, dimethyl sulfoxide- $d_{6}$; FT-IR spectroscopy, fourier transform infrared spectroscopy; KDa, Kilo Dalton.

2.1.1. Synthesis of Substituted Aromatic Esters 2 (a-e) and Aromatic Acid Hydrazides $3(\boldsymbol{a}-\boldsymbol{e})$. Substituted aromatic acid $\mathbf{1}$ was esterified 2 by refluxing in methanol and in the presence of catalytic amount of sulfuric acid. Substituted aromatic ester 2 was converted into their corresponding acid hydrazide 3 by refluxing in hydrazine hydrate and methanol was used as solvent through reported literature procedure [22-24].

2.1.2. Synthesis of 1,3,4-oxadiazole-2-thiones. Acid hydrazides 3 was treated with carbon disulfide in ethanolic potassium hydroxide under reflux to give 5-(substituted) 1,3,4oxadiazole-2-thione. The recrystallization with ethanol afforded pure oxadiazoles.

5-(2,3,4-Trimethoxyphenyl)-1,3,4-oxadiazole-2(3H)-thione (4a). Light yellow solid; yield: $74 \% ; \mathrm{mp} 132-134^{\circ} \mathrm{C} ; R_{f}$ : 0.72 (chloroform : methanol, $9: 1)$; IR $\left(\nu / \mathrm{cm}^{-1}\right)$ : 3178, 3032, 2918, 2867, 1568, 1526, 1479; ${ }^{1} \mathrm{H}$ NMR (300 MHz, DMSO$\left.d_{6}\right) \delta 13.23(\mathrm{~s}, 1 \mathrm{H}, \mathrm{NH}), 7.34(\mathrm{~d}, 1 \mathrm{H}, J=7.8 \mathrm{~Hz}, \mathrm{Ar}-\mathrm{H}), 7.21$ (d, $1 \mathrm{H}, J=7.8 \mathrm{~Hz}, \mathrm{Ar}-\mathrm{H}), 3.73\left(\mathrm{~s}, 3 \mathrm{H}, \mathrm{OCH}_{3}\right) 3.65$ (s, 3H,
$\left.\mathrm{OCH}_{3}\right), 3.58\left(\mathrm{~s}, 3 \mathrm{H}, \mathrm{OCH}_{3}\right) ;{ }^{13} \mathrm{C}$ NMR (75 MHz, DMSO-d $)$ $\delta 178.25,163.74,160.03,160.20,159.93,134.66,132.43$, 127.63, 56.23, 55.56, 55.34; Anal. Calcd for $\mathrm{C}_{11} \mathrm{H}_{12} \mathrm{~N}_{2} \mathrm{O}_{4} \mathrm{~S}: \mathrm{C}$, 49.24; H, 4.51; N, 10.44; O, 23.85; S, 11.95; Found: C, 49.23; H, 4.52; N, 10.43; O, 23.86; S, 11.94 .

5-(1H-Indol-2-yl)-1,3,4-oxadiazole-2(3H)-thione (4b). Brown solid; yield: $76 \%$; mp $122-124^{\circ} \mathrm{C} ; R_{f}$ : 0.74 (chloroform : methanol, 9:1); IR $\left(\nu / \mathrm{cm}^{-1}\right): 3167,3029,2947,2849$, 1581, 1537, 1486; ${ }^{1} \mathrm{H}$ NMR $\left(300 \mathrm{MHz}, \mathrm{DMSO}-d_{6}\right) \delta 13.23$ (s, 1H, NH), 8.71 (s, 1H, NH), $7.62(\mathrm{~m}, 1 \mathrm{H}, \mathrm{Ar}-\mathrm{H}), 7.47$ (m, 1H, Ar-H), 6.92 (s, 1H, Ar-H), 6.80 (m, 2H, Ar-H); ${ }^{13} \mathrm{C}$ NMR $\left(75 \mathrm{MHz}, \mathrm{DMSO}-d_{6}\right) \delta 178.25,162.26,161.28,152.20$, 146.34, 134.66, 132.43, 127.63, 126.36, 124.12; Anal. Calcd for $\mathrm{C}_{10} \mathrm{H}_{7} \mathrm{~N}_{3} \mathrm{OS}$ : C, 55.29; H, 3.25; N, 19.34; O, 7.36; S, 14.76; Found: C, 55.30; H, 3.26; N, 19.32; O, 7.34; S, 14.77.

5-(4-Bromobenzyl)-1,3,4-oxadiazole-2(3H)-thione (4c). White solid; yield: $71 \%$; mp: $126-128^{\circ} \mathrm{C} ; R_{f}$ : 0.74 (chloroform : methanol, 9:1); IR $\left(\nu / \mathrm{cm}^{-1}\right)$ : 3205, 3087, 2953, 2826, $1569,1517,1511,1495,1484$; ${ }^{1} \mathrm{H}$ NMR (300 MHz, DMSO$\left.d_{6}\right) \delta 14.26(\mathrm{~s}, 1 \mathrm{H}, \mathrm{NH}), 7.57-7.46(\mathrm{~m}, 2 \mathrm{H}, \mathrm{Ar}-\mathrm{H}), 7.23-$ $7.16(\mathrm{~m}, 2 \mathrm{H}, \mathrm{Ar}-\mathrm{H}), 3.99$ (s, 2H, $\left.\mathrm{CH}_{2}\right) ;{ }^{13} \mathrm{C} \mathrm{NMR}(75 \mathrm{MHz}$, DMSO- $\left.d_{6}\right) \delta 178.25,160.23,136.55,131.54,129.32,127.34$, 123.52, 118.37, 30.63; Anal. Calcd for $\mathrm{C}_{9} \mathrm{H}_{7} \mathrm{BrN}_{2} \mathrm{OS}$ : C, 39.87; H, 2.60; N, 10.33; S, 11.83; Found: C, 39.80; H, 2.54; $\mathrm{N}, 10.28 ; \mathrm{S}, 11.77$.

5-(4-Methylbenzyl)-1,3,4-oxadiazole-2(3H)-thione (4d). Light yellow solid; yield: $74 \%$; mp $125-127^{\circ} \mathrm{C} ; R_{f}$ : 0.68 (chloroform:methanol, 9:1); IR $\left(\nu / \mathrm{cm}^{-1}\right): 3184,3045,2939$, 2849, 1593, 1522, 1489; ${ }^{1} \mathrm{H}$ NMR (300 MHz, DMSO- $\left.d_{6}\right)$ $\delta 13.25(\mathrm{~s}, 1 \mathrm{H}, \mathrm{NH}), 7.18-7.11(\mathrm{~m}, 2 \mathrm{H}, \mathrm{Ar}-\mathrm{H}), 6.85-6.78$ $(\mathrm{m}, 2 \mathrm{H}, \mathrm{Ar}-\mathrm{H}), 4.17\left(\mathrm{~s}, 2 \mathrm{H}, \mathrm{CH}_{2}\right), 2.51\left(\mathrm{~s}, 3 \mathrm{H}, \mathrm{CH}_{3}\right) ;{ }^{13} \mathrm{C}$ NMR $\left(75 \mathrm{MHz}\right.$, DMSO- $\left.d_{6}\right) \delta 178.35,161.88,142.03,132.13$, 128.25, 124.76, 123.75, 118.19, 31.47, 26.55; Anal. Calcd for $\mathrm{C}_{10} \mathrm{H}_{10} \mathrm{~N}_{2} \mathrm{OS}$ : C, 58.23; H, 4.89; N, 13.58; O, 7.76; S, 15.55; Found: C, 58.24; H, 4.89; N, 13.57; O, 7.75; S, 15.56.

5-(3,4-Dichlorobenzyl)-1,3,4-oxadiazole-2(3H)-thione (4e). Light yellow solid; yield: $76 \%$; mp: $123-125^{\circ} \mathrm{C} ; R_{f}: 0.73$ (chloroform: methanol, 9:1); IR $\left(\nu / \mathrm{cm}^{-1}\right)$ : 3201, 3019, 2936, 2859, 1593, 1536, 1489; ' ${ }^{1} \mathrm{H}$ NMR (300 MHz, DMSO$\left.d_{6}\right) \delta 14.17(\mathrm{~s}, 1 \mathrm{H}, \mathrm{NH}), 7.65-7.56(\mathrm{~m}, 1 \mathrm{H}, \mathrm{Ar}-\mathrm{H}), 7.24-7.38$ $(\mathrm{m}, 2 \mathrm{H}, \mathrm{Ar}-\mathrm{H}), 4.31\left(\mathrm{~s}, 2 \mathrm{H}, \mathrm{CH}_{2}\right) ;{ }^{13} \mathrm{C} \mathrm{NMR}(75 \mathrm{MHz}$, DMSO- $\left.d_{6}\right) \delta 178.21,162.21,149.12,147.99,134.65,132.47$, 129.41, 126.37, 27.88; Anal. Calcd for $\mathrm{C}_{9} \mathrm{H}_{6} \mathrm{Cl}_{2} \mathrm{~N}_{2} \mathrm{OS}$ : C, 41.40; H, 2.32; N, 10.73; S, 12.28; Found: C, 41.30; H, 2.25; $\mathrm{N}, 10.65 ; \mathrm{S}, 12.19$.

5-(2-Fluorobenzyl)-1,3,4-oxadiazole-2(3H)-thione (4f). Dull white solid; yield: $69 \%$; mp: $131-133^{\circ} \mathrm{C} ; R_{f}$ : 0.73 (chloroform : methanol, 9:1); IR $\left(\nu / \mathrm{cm}^{-1}\right): 3191,3057,2915,2881$, $1590,1521,1502,1485 ;{ }^{1} \mathrm{H}$ NMR $\left(300 \mathrm{MHz}, \mathrm{DMSO}-d_{6}\right)$ $\delta 14.34(\mathrm{~s}, 1 \mathrm{H}, \mathrm{NH}), 7.48-7.35(\mathrm{~m}, 2 \mathrm{H}, \mathrm{Ar}-\mathrm{H}), 7.29-7.18$ $(\mathrm{m}, 2 \mathrm{H}, \mathrm{Ar}-\mathrm{H}), 4.18\left(\mathrm{~s}, 2 \mathrm{H}, \mathrm{CH}_{2}\right) ;{ }^{13} \mathrm{C} \mathrm{NMR}(75 \mathrm{MHz}$, DMSO- $\left.d_{6}\right) \delta 178.29,162.52,159.98,132.18,130.50,125.27$, 120.93, 116.13, 25.50; Anal. Calcd for $\mathrm{C}_{9} \mathrm{H}_{7} \mathrm{FN}_{2} \mathrm{OS}$ : C, 51.42; 
H, 3.36; N, 13.33; S, 15.25; Found: C, 51.34; H, 3.28; N, 13.23; S, 15.17 .

5-(4-Methoxyphenethyl)-1,3,4-oxadiazole-2(3H)-thione $(\mathbf{4} \mathbf{g})$. Light yellow solid; yield: $89 \%$; mp $76-78^{\circ} \mathrm{C} ; R_{f}$ : 0.78 (chloroform : methanol, $9: 1)$; IR $\left(\nu / \mathrm{cm}^{-1}\right)$ : 3233, 3072, 2937, 2812, $1583,1509,1483 ;{ }^{1} \mathrm{H}$ NMR $\left(300 \mathrm{MHz}, \mathrm{DMSO}-d_{6}\right) \delta 14.31(\mathrm{~s}$, $1 \mathrm{H}, \mathrm{NH}), 7.28-7.15$ (m, 2H, Ar-H), 6.88-6.72 (m, 2H, Ar$\mathrm{H}), 2.91\left(\mathrm{t}, 2 \mathrm{H}, J=7.8 \mathrm{~Hz}, \mathrm{CH}_{2}\right), 2.88(\mathrm{t}, 2 \mathrm{H}, J=7.8 \mathrm{~Hz}$, $\left.\mathrm{CH}_{2}\right), 3.72\left(\mathrm{~s}, 3 \mathrm{H}, \mathrm{OCH}_{3}\right) ;{ }^{13} \mathrm{C} \mathrm{NMR}(75 \mathrm{MHz}, \mathrm{DMSO}-$ $\left.d_{6}\right) \delta 178.14,163.98,159.91,140.47,130.92,127.94,121.40$, 118.36, 55.66, 31.24, 26.89; Anal. Calcd for $\mathrm{C}_{11} \mathrm{H}_{12} \mathrm{~N}_{2} \mathrm{O}_{2} \mathrm{~S}_{9}$ : C, 55.91; H, 5.12; N, 11.86; S, 13.57; Found: C, 55.86; H, 5.07; N, 11.77; S, 13.47 .

5-(2,4-Dichlorobenzyl)-1,3,4-oxadiazole-2(3H)-thione (4h). White solid; yield: $70 \%$; mp $119-121^{\circ} \mathrm{C}$; $R_{f}$ : 0.72 (chloroform : methanol, $9: 1)$; IR $\left(\nu / \mathrm{cm}^{-1}\right): 3214,3014,2915,2839$, 1569, 1521,1482; ${ }^{1} \mathrm{H}$ NMR (300 MHz, DMSO-d 6 ) $\delta 14.19$ (s, 1H, NH), 7.73-7.63 (m, 1H, Ar-H), 7.26-7.17 (m, 2H, Ar-H), 4.29 (s, 2H, CH 2 ); ${ }^{13} \mathrm{C}$ NMR (75 MHz, DMSO- $d_{6}$ ) $\delta$ 178.33, 161.32, 147.76, 147.19, 136.45, 133.25, 129.41, 126.37, 27.88; Anal. Calcd for $\mathrm{C}_{9} \mathrm{H}_{6} \mathrm{Cl}_{2} \mathrm{~N}_{2} \mathrm{OS}$ : C, 41.40; $\mathrm{H}$, 2.32; N, 10.73; S, 12.28; Found: C, 41.32; H, 2.21; N, 10.65; S, 12.19 .

5-(2-Methoxyphenethyl)-1,3,4-oxadiazole-2(3H)-thione (4i). Yellow solid; yield: $71 \%$; mp $85-87^{\circ} \mathrm{C} ; R_{f}$ : 0.78 (chloroform : methanol, 9: 1); IR $\left(\nu / \mathrm{cm}^{-1}\right)$ : 3195, 3052, 2936, 2845, $1592,1522,1485 ;{ }^{1} \mathrm{H}$ NMR $\left(300 \mathrm{MHz}, \mathrm{DMSO}-d_{6}\right) \delta 14.36$ (s, 1H, NH), 7.26-7.12 (m, 2H, Ar-H), 7.01-6.92 (m, 1H, Ar-H), 6.90-6.85 (m, 1H, Ar-H), 2.94 (t, 2H, $J=7.8 \mathrm{~Hz}$, $\left.\mathrm{CH}_{2}\right), 2.49\left(\mathrm{t}, 2 \mathrm{H}, \mathrm{J}=7.8 \mathrm{~Hz}, \mathrm{CH}_{2}\right), 3.75\left(\mathrm{~s}, 3 \mathrm{H}, \mathrm{OCH}_{3}\right)$; ${ }^{13} \mathrm{C}$ NMR (75 MHz, DMSO- $\left.d_{6}\right) \delta 178.19,162.79,159.63$, $141.43,130.91,122.34,119.48,114.96,55.51,29.36,26.89$; Anal. Calcd for $\mathrm{C}_{11} \mathrm{H}_{12} \mathrm{~N}_{2} \mathrm{O}_{2} \mathrm{~S}_{9}$ : C, 55.91; H, 5.12; N, 11.86; S, 13.57; Found: C, 55.78; H, 5.02; N, 11.86; S, 13.57 .

5-(4-Chlorobenzyl)-1,3,4-oxadiazole-2(3H)-thione (4j). Yellow solid; yield: $69 \%$; mp $112-114^{\circ} \mathrm{C}$; $R_{f}$ : 0.70 (chloroform : methanol, $9: 1)$; IR $\left(\nu / \mathrm{cm}^{-1}\right)$ : 3223, 3049, 2915, 2856, 1582, 1537, 1498; ${ }^{1} \mathrm{H}$ NMR (300 MHz, DMSO-d $) \delta 14.31$ (s, 1H, NH), 7.25-7.18 (m, 2H, Ar-H), 7.09-6.95 (m, 2H, Ar-H), $4.21\left(\mathrm{~s}, 2 \mathrm{H}, \mathrm{CH}_{2}\right) ;{ }^{13} \mathrm{C}$ NMR $\left(75 \mathrm{MHz}, \mathrm{DMSO}-d_{6}\right) \delta$ 178.37, 162.19, 158.87, 133.55, 132.43, 130.07,126.97, 120.12, 31.41; Anal. Calcd for $\mathrm{C}_{9} \mathrm{H}_{7} \mathrm{ClN}_{2} \mathrm{OS}$ : C, 47.69; H, 3.11; Cl, 15.64; N, 12.36; O, 7.06; S, 14.15; Found: C, 47.69; H, 3.11; $\mathrm{Cl}, 15.64 ; \mathrm{N}, 12.36 ; \mathrm{O}, 7.06 ; \mathrm{S}, 14.15$.

5-(2-Chlorobenzyl)-1,3,4-oxadiazole-2(3H)-thione (4k). Pink solid; yield: $68 \%$; mp $112-114^{\circ} \mathrm{C}$; $R_{f}$ : 0.71 (chloroform : methanol, 9:1); IR $\left(\nu / \mathrm{cm}^{-1}\right): 3182,3035,2952,2856$, $1569,1488,1466,1437 ;{ }^{1} \mathrm{H}$ NMR $\left(300 \mathrm{MHz}, \mathrm{DMSO}-d_{6}\right) \delta$ 14.44 (s, 1H, NH), 7.59-7.46 (m, 2H, Ar-H), 7.42-7.38 (m, $2 \mathrm{H}, \mathrm{Ar}-\mathrm{H}), 4.26$ (s, 2H, $\left.\mathrm{CH}_{2}\right) ;{ }^{13} \mathrm{C}$ NMR (75 MHz, DMSO$\left.d_{6}\right) \delta 178.26,151.24,133.85,132.36,131.65,130.18,128.13$, 124.12, 29.87; Anal. Calcd for $\mathrm{C}_{9} \mathrm{H}_{7} \mathrm{ClN}_{2} \mathrm{OS}$ : C, 39.87; H,
2.60; N, 10.33; S, 11.83; Found: C, 39.79; H, 2.47; N, 10.25; S, 11.65 .

5-(4-Methoxybenzyl)-1,3,4-oxadiazole-2(3H)-thione (4l). Light yellow solid; yield: $70 \%$ mp $107-109^{\circ} \mathrm{C} ; R_{f}: 0.72$ (chloroform: methanol, 9:1); IR $\left(\nu / \mathrm{cm}^{-1}\right)$ : 3181, 3011, 2914, 2876, 1575, 1508, 1488; ${ }^{1} \mathrm{H}$ NMR (300 MHz, DMSO$\left.d_{6}\right) \delta 13.29(\mathrm{~s}, 1 \mathrm{H}, \mathrm{NH}), 7.29-7.19(\mathrm{~m}, 2 \mathrm{H}, \mathrm{Ar}-\mathrm{H}), 6.97-6.86$ (m, 2H, Ar-H), 4.05 (s, 2H, $\left.\mathrm{CH}_{2}\right), 3.73$ (s, 3H, $\left.\mathrm{OCH}_{3}\right) ;{ }^{13} \mathrm{C}$ NMR $\left(75 \mathrm{MHz}, \mathrm{DMSO}-d_{6}\right) \delta 178.25,163.74,160.03,130.64$, 127.05, 125.66, 120.43, 114.63, 55.56, 30.64; Anal. Calcd for $\mathrm{C}_{10} \mathrm{H}_{10} \mathrm{~N}_{2} \mathrm{O}_{2} \mathrm{~S}$ : C, 54.04; H, 4.53; N, 12.60; S, 14.43; Found: C, $54.01 ; \mathrm{H}, 4.41 ; \mathrm{N}, 12.45 ; \mathrm{S}, 14.35$.

5-(2-Methoxybenzyl)-1,3,4-oxadiazole-2(3H)-thione (4m). White solid; yield: $62 \%$; $\mathrm{mp} \quad 112-114^{\circ} \mathrm{C} ; \mathrm{R}_{f:} 0.72$ (chloroform: methanol, 9:1); IR $\left(\nu / \mathrm{cm}^{-1}\right)$ : 3199, 3014, 2936, 2871, 1574, 1512, 1489, 1480; ${ }^{1} \mathrm{H}$ NMR $(300 \mathrm{MHz}$, DMSO- $\left.d_{6}\right) \delta 14.34(\mathrm{~s}, 1 \mathrm{H}, \mathrm{NH}), 7.38-7.23(\mathrm{~m}, 2 \mathrm{H}, \mathrm{Ar}-\mathrm{H})$, 7.08-7.09 (m, 1H, Ar-H), 6.99-6.91 (m, 1H, Ar-H), 4.04 $\left(\mathrm{s}, 2 \mathrm{H}, \mathrm{CH}_{2}\right), 3.77\left(\mathrm{~s}, 3 \mathrm{H}, \mathrm{OCH}_{3}\right) ;{ }^{13} \mathrm{C} \mathrm{NMR}(75 \mathrm{MHz}$, DMSO- $\left.d_{6}\right) \delta 178.16,163.33,157.52,131.11,129.68,121.72$, 121.00, 111.64, 56.02, 26.56; Anal. Calcd for $\mathrm{C}_{10} \mathrm{H}_{10} \mathrm{~N}_{2} \mathrm{O}_{2} \mathrm{~S}$ : C, 54.04; H, 4.53; N, 12.60; S, 14.43; Found: C, 53.92; H, $4.42 ; \mathrm{N}, 12.43 ; \mathrm{S}, 14.23$.

5-(3-Methoxybenzyl)-1,3,4-oxadiazole-2(3H)-thione (4n). Light pink solid; yield: $75 \%$; mp $93-95^{\circ} \mathrm{C} ; R_{f}: 0.69$ (chloroform: methanol, 9:1); IR $\left(\nu / \mathrm{cm}^{-1}\right)$ : 3202, 3002, 2935, 2839, 1568, 1531, 1489, 1473; ${ }^{1} \mathrm{H}$ NMR $(300 \mathrm{MHz}$, DMSO- $\left.d_{6}\right) \delta 14.43(\mathrm{~s}, 1 \mathrm{H}, \mathrm{NH}), 7.33-7.24(\mathrm{~m}, 1 \mathrm{H}, \mathrm{Ar}-\mathrm{H})$, 6.93-6.84 (m, 3H, Ar-H), $4.10\left(\mathrm{~s}, 2 \mathrm{H}, \mathrm{CH}_{2}\right), 3.74(\mathrm{~s}, 3 \mathrm{H}$, $\left.\mathrm{OCH}_{3}\right) ;{ }^{13} \mathrm{C}$ NMR $\left(75 \mathrm{MHz}, \mathrm{DMSO}-d_{6}\right) \delta 178.30,163.32$, 159.92, 135.32, 130.32, 121.61, 115.31, 113.29, 55.53, 31.45; Anal. Calcd for $\mathrm{C}_{10} \mathrm{H}_{10} \mathrm{~N}_{2} \mathrm{O}_{2} \mathrm{~S}$ : C, 54.04; H, 4.53; N, 12.60; S, 14.43; Found: C, 53.94; H, 4.44; N, 12.52; S, 14.22.

5-(3-Methoxyphenethyl)-1,3,4-oxadiazole-2(3H)-thione (4o). Dull white solid; yield: $77 \%$; mp $78-80^{\circ} \mathrm{C} ; R_{f}: 0.76$ (chloroform : methanol, $9: 1)$; IR $\left(\nu / \mathrm{cm}^{-1}\right): 3190,3071,2979,2836$, 1581, 1508, 1491; ${ }^{1} \mathrm{H}$ NMR (300 MHz, DMSO-d 6 ) $\delta 14.29$ (s, 1H, NH), 7.21-7.11 (m, 1H, Ar-H), 6.92-6.66 (m, 3H, Ar-H), 2.86 (t, 2H, J = 7.6 Hz, $\left.\mathrm{CH}_{2}\right), 2.77(\mathrm{t}, 2 \mathrm{H}, J=7.6 \mathrm{~Hz}$, $\left.\mathrm{CH}_{2}\right), 3.78\left(\mathrm{~s}, 3 \mathrm{H}, \mathrm{OCH}_{3}\right) ;{ }^{13} \mathrm{C} \mathrm{NMR}\left(75 \mathrm{MHz}, \mathrm{DMSO}-d_{6}\right)$ $\delta$ 178.19, 163.99, 160.17, 141.46, 130.91, 122.34, 119.48, 114.96, 55.51, 29.36, 26.12; Anal. Calcd for $\mathrm{C}_{11} \mathrm{H}_{12} \mathrm{~N}_{2} \mathrm{O}_{2} \mathrm{~S}_{9}$ : C, 55.91; H, 5.12; N, 11.86; S, 13.57; Found: C, 55.43; H, $5.01 ; \mathrm{N}, 11.80 ; \mathrm{S}, 13.49$.

5-(Pyridin-3-yl)-1,3,4-oxadiazole-2(3H)-thione (4p). Light yellow solid; yield: $766 \%$; mp $94-96^{\circ} \mathrm{C} ; R_{f}: 0.73$ (chloroform : methanol, 9:1); IR $\left(\nu / \mathrm{cm}^{-1}\right): 3218,3079,2958,2847$, $1549,1526,1492,1488 ;{ }^{1} \mathrm{H}$ NMR $\left(300 \mathrm{MHz}, \mathrm{DMSO}-d_{6}\right) \delta$ 14.17 (s, 1H, NH), 8.98 (s, 1H, Ar-H), 8.40 (m, 1H, Ar-H), $8.27(\mathrm{~m}, \mathrm{Ar}-\mathrm{H}), 7.54(\mathrm{~m}, 1 \mathrm{H}, \mathrm{Ar}-\mathrm{H}) ;{ }^{13} \mathrm{C} \mathrm{NMR}(75 \mathrm{MHz}$, DMSO- $\left.d_{6}\right) \delta 178.32,161.12,154.56,152.13,134.56,130.32$, 121.31; Anal. Calcd for $\mathrm{C}_{7} \mathrm{H}_{5} \mathrm{~N}_{3}$ OS: C, 46.92; $\mathrm{H}, 2.81 ; \mathrm{N}$, 
23.45; O, 8.93; S, 17.89; Found: C, 46.93; H, 2.80; N, 23.47; $\mathrm{O}, 8.91 ; \mathrm{S}, 17.5$.

5-(2,6-Dichlorobenzyl)-1,3,4-oxadiazole-2(3H)-thione (4q). White solid; yield: $74 \%$; mp $127-129^{\circ} \mathrm{C}$; $R_{f}: 0.73$ (chloroform: methanol, 9: 1); IR $\left(v / \mathrm{cm}^{-1}\right): 3235,3041,2951,2874$, $1582,1545,1498 ;{ }^{1} \mathrm{H}$ NMR (300 MHz, DMSO- $\left.d_{6}\right) \delta 14.21$ (s, 1H, NH), 7.65-7.57 (m, 2H, Ar-H), 7.31-7.26 (m, 1H, Ar-H), 4.34 (s, $\left.2 \mathrm{H}, \mathrm{CH}_{2}\right) ;{ }^{13} \mathrm{C}$ NMR $\left(75 \mathrm{MHz}, \mathrm{DMSO}-d_{6}\right)$ $\delta$ 178.37, 160.28, 158.17, 157.26, 135.48, 131.41, 129.92, 123.21, 30.24; Anal. Calcd for $\mathrm{C}_{9} \mathrm{H}_{6} \mathrm{Cl}_{2} \mathrm{~N}_{2} \mathrm{OS}$ : C, 41.40; $\mathrm{H}$, 2.32; N, 10.73; S, 12.28; Found: C, 41.32; H, 2.21; N, 10.65; S, 12.19 .

5-(4-Chloro-2-fluorophenyl)-1,3,4-oxadiazole-2(3H)-thione (4r). White solid; yield: $69 \%$; $\mathrm{mp} 98-100^{\circ} \mathrm{C} ; R_{f}: 0.75$ (chloroform:methanol, 9:1); IR $\left(\nu / \mathrm{cm}^{-1}\right)$ : 3199, 3042, 2939, 2832, 1572, 1512, 1488, 1476; ${ }^{1} \mathrm{H}$ NMR $(300 \mathrm{MHz}$, DMSO- $\left.d_{6}\right) \delta 14.21(\mathrm{~s}, 1 \mathrm{H}, \mathrm{NH}), 7.72-7.67(\mathrm{~m}, 1 \mathrm{H}, \mathrm{Ar}-\mathrm{H})$, 7.42-7.38(m, $2 \mathrm{H}, \mathrm{Ar}-\mathrm{H}) ;{ }^{13} \mathrm{C}$ NMR $\left(75 \mathrm{MHz}, \mathrm{DMSO}-d_{6}\right)$ $\delta 178.31,162.22,150.01,136.29,133.41,131.65,130.18$, 119.21; Anal. Calcd for $\mathrm{C}_{8} \mathrm{H}_{4} \mathrm{ClFN}_{2} \mathrm{OS}$ : C, 39.87; $\mathrm{H}, 2.60 ; \mathrm{N}$, 10.33; S, 11.83; Found: C, 39.78; H, 2.55; N, 10.27; S, 11.67 .

2.2. Urease Assay and Inhibition. Indophenols method was used for the quantification of ammonia and the enzyme activity was determined by measuring its absorbance [25]. In brief, $40 \mu \mathrm{L}$ buffer ( $100 \mathrm{mM}$ urea, $1 \mathrm{mM}$ EDTA, $0.01 \mathrm{M}$ $\left.\mathrm{K}_{2} \mathrm{HPO}_{4}, 0.01 \mathrm{M} \mathrm{LiCl}_{2}, \mathrm{pH} 8.2\right), 10 \mu \mathrm{L}$ of test compound and $10 \mu \mathrm{L}$ of enzyme $(5 \mathrm{U} / \mathrm{mL})$ were incubated in a 96 well plate for 10 minutes at $37^{\circ} \mathrm{C}$. In addition, solutions of $40 \mu \mathrm{L}$ of phenol reagent $(1 \%, \mathrm{w} / \mathrm{v}$ phenol, $0.005 \%, \mathrm{w} / \mathrm{v}$ sodium nitroprusside) and $40 \mu \mathrm{L}$ of alkali reagent $(0.5 \%$, w/v NaOH, $0.1 \%$ active chloride $\mathrm{NaOCl}$ ) were introduced to each well. Experiments were performed in a triplicate fashion and thiourea was used as standard inhibitor. Microplate reader (Bio-TekELx 800, Instruments, Inc., USA) was used to read the absorbance at $625 \mathrm{~nm}$. The percentage inhibition was calculated using the following equation $100-$ $\left(\mathrm{OD}_{\text {test well }} / \mathrm{OD}_{\text {control }}\right) \times 100$. The results were calculated using PRISM 5.0 (GraphPad, San Diego, CA, USA).

2.3. Measurement of Antibacterial Activity. The antibacterial activity data is represented in Table 2. Some derivatives of 1,3,4-oxadiazole have shown even more potency than the standard drug ciprofloxacin while some of them have comparable potency against different strains. Ciprofloxacin was used as standard drug. The compounds were found active against bacterial strains (2 Gram positive bacteria, namely, Staphylococcus aureus, Bacillus subtilis, and 2 Gram negative bacteria namely Escherichia coli, Shigella flexneri) in variable concentration. The antibacterial activities of 1,3,4-oxadiazole derivatives were evaluated in vitro by serial tube dilution method. The compounds and standard drug ciprofloxacin were dissolved in $\mathrm{N}, \mathrm{N}$-dimethylformamide (DMF) to give a concentration of $5 \mu \mathrm{g} / \mathrm{mL}$ (stock solution). Necessary apparatus and test tubes set of capacity $5 \mathrm{~mL}$ was washed cleaned and completely dried. For the bacterial culture double strength nutrient broth was used. The culture media was made by dissolving $15 \mathrm{~g}$ of nutrient broth in $1 \mathrm{~L}$ of distilled water. Approximately, $1 \mathrm{~mL}$ of culture media was prepared and transferred to each test tube by micropipette and capped with non-adsorbent cotton plugs. The test tubes containing $1 \mathrm{~mL}$ culture media was sterilized in an autoclave at $121^{\circ} \mathrm{C}$ for $20 \mathrm{~min}$ at $15 \mathrm{psi}$ pressure. Subculturing of bacteria was done by transferring a loopful of particular bacterial strain from standard bacterial agar to $10 \mathrm{~mL}$ sterilized nutrient broth aseptically in a laminar air flow cabinet. It was then incubated for a period of $24 \mathrm{~h}$ at $37^{\circ} \mathrm{C}$ in a B. O. D. incubator. Bacterial strain suspension was prepared, after $24 \mathrm{~h}$ incubation, by aseptically inoculating $0.2 \mathrm{~mL}$ of revived bacterial colony into $100 \mathrm{~mL}$ of $0.9 \% \mathrm{~m} / \mathrm{v}$ saline. A series of 5 assay tubes for a single derivative against each bacterial strain was employed. A stock solution of each test derivative at concentration $5 \mu \mathrm{g} / \mathrm{mL}$ (containing $1 \mathrm{~mL}$ nutrient broth) was serially diluted to achieve concentrations of $2.5,1.25,0.625,0.313$, and $0.156 \mu \mathrm{g} / \mathrm{mL}$. Then, $0.1 \mathrm{~mL}$ of normal saline suspension of revived bacteria was added to each test tube. The inoculated tubes were incubated at $37^{\circ} \mathrm{C}$ for $24 \mathrm{~h}$. The MIC (minimum inhibitory concentration) values were determined by subsequently checking for the absence of visual turbidity.

2.4. Measurement of Antioxidant Activity. The free radical scavenging capacity of the compounds was measured by 1,1diphenyl-2-picrylhydrazyl. Test compounds were allowed to react with stable free radical, 1,1-diphenyl-2-picrylhydrazyl radical (DPPH) for half an hour at $37^{\circ} \mathrm{C}$. The concentration of DPPH was kept as $300 \mu \mathrm{M}$. The test samples were dissolved in DMSO while the DPPH solution was prepared in ethanol. After incubation, decrease in absorption was measured at $515 \mathrm{~nm}$ using microplate reader. Percent radical scavenging activity of samples was determined in comparison with a DMSO treated as control. Propyl gallate and 3-tert-Butyl-4hydroxyanisole were used as standards.

2.5. Enzyme and Compounds Preparation for Docking. Docking study was performed by using the available crystal structure of Jack bean urease from Protein Data Bank (PDB code: 3LA4). It is very crucial to carefully prepare the protein and small molecule structures before using them in the docking calculations. The enzyme structure was prepared using MOE program. Protonation was performed using the Protonate3D algorithm implemented in MOE. Force-field-based parameterization and energy minimization was carried out by choosing Amber99 force-field library. Correct protonation and metal atoms states for the active site histidine residues and two $\mathrm{Ni}^{+2}$ ions were assigned. By using Protonate3D algorithm, the four histidine residues surrounding the $\mathrm{Ni}^{+2}$ ions in the active site pocket of the enzyme were protonated according to the bound state of the two $\mathrm{Ni}^{+2}$ ions. Wrong protonation states of the active site histidine residues can lead to a drastic effect on the binding modes of the ligands during docking. After protonation and force-field-based parameterization setup, the enzyme structure was energy minimized. During energy minimization, the protein heavy 
atoms were restrained to avoid changes in the active site pocket and to allow only the relaxation in protein side chains and added hydrogens. After energy minimization, the cocrystallized bound compounds and water molecules were stripped off from the crystal structure.

Similarly, the compounds structures were also prepared before carrying out docking calculations. It is also very important to prepare the correct protonation and ionization states of the small molecule structures. 3D conformations were generated for the compounds followed by energy minimization by choosing MMFF94x force-field and using the "wash" module in MOE.

2.6. Docking Calculations. The docking calculations were carried out using FlexX [26] program. The enzyme's active site pocket was defined by setting $10 \AA$ spacing around the cocrystallized bound $\mathrm{PO}_{4}$. The nonstandard protein residues and single metal ions were included in the binding site definition. The two $\mathrm{Ni}^{+2}$ metal atoms were selected as metal pharmacophores. The geometry parameters for the two metal atoms were set up as automated spheres. The default docking and scoring parameters were used for docking calculations and the top 10 best conformations that fulfilled the metal pharmacophore criteria were retained for further analysis.

\section{Results and Discussion}

3.1. General Procedure for Synthesis. Synthesis for target compounds, 1,3,4-oxadiazole $4(\mathbf{a}-\mathbf{r})$ is illustrated in Scheme 1. Substituted aromatic esters $2(\mathbf{a}-\mathbf{r})$ were synthesized by the reaction of corresponding substituted aromatic acids $\mathbf{1}(\mathbf{a}-\mathbf{r})$ in the presence of catalytic amount of sulfuric acid, the esters $2(\mathbf{a}-\mathbf{r})$ were converted into corresponding aromatic acid hydrazides $\mathbf{3}(\mathbf{a}-\mathbf{r})$ by refluxing with hydrazine hydrate $(80 \%)$ in methanol. Treatment of the aromatic acid hydrazides $3(\mathbf{a}-\mathbf{r})$ with carbon disulfide in the presence of potassium hydroxide and ethanol under reflux afford corresponding oxadiazole $4(a-r)$.

3.2. Urease Inhibition Assay. The synthesized compounds were tested for their in vitro urease inhibition against Jack bean urease. Thiourea was used as a standard inhibitor in assay having $\mathrm{IC}_{50}$ value of $22.3 \pm 12 \mu \mathrm{M}$. Most of the compounds of this series showed promising urease inhibitory potency. The results indicated that ortho and para substituted benzene in the vicinity of parent oxadiazole core is important to obtain the potent activity. It is observed from the results that methoxy substituted benzene next to oxadiazole ring and halo-substituted compounds showed excellent urease inhibition.

Potent compounds have their activities in the range of $1.15 \mu \mathrm{M}$ to $42.42 \mu \mathrm{M}$ (Table 1). Among investigated compounds, $4 \mathbf{j}$ bearing a 4 -chlorobenzyl ring, was found to be the most active urease inhibitor with an $\mathrm{IC}_{50}$ value of $1.15 \pm 0.2 \mu \mathrm{M}$. Compounds $4 \mathrm{a}$ bearing methoxy group at 2,3,4 positions and $4 \mathbf{g}, 4 \mathbf{i}, 4 \mathbf{l}, 4 \mathrm{~m}$ also showed strong inhibitory activities in the range of $5.6 \mu \mathrm{M}$ to $6.22 \mu \mathrm{M}$. These
TABLE 1: Inhibitory activity of 1,3,4-oxadiazoles derivatives against Jack bean urease.

\begin{tabular}{lc}
\hline Compound & $\mathrm{IC}_{50} \pm$ SEM $(\mu \mathrm{M})$ (or \% inhibition) \\
\hline $\mathbf{4 a}$ & $5.79 \pm 0.3$ \\
$\mathbf{4 b}$ & $21.3 \pm 0.7$ \\
$\mathbf{4 c}$ & $11.8 \pm 0.4$ \\
$\mathbf{4 e}$ & $11.3 \pm 0.6$ \\
$\mathbf{4 f}$ & $3.27 \pm 0.3$ \\
$\mathbf{4 g}$ & $5.61 \pm 0.3$ \\
$\mathbf{4 h}$ & $42.4 \pm 1.2$ \\
$\mathbf{4 i}$ & $6.22 \pm 0.4$ \\
$\mathbf{4 j}$ & $1.15 \pm 0.2$ \\
$\mathbf{4 k}$ & $12.9 \pm 0.6$ \\
$\mathbf{4 l}$ & $5.83 \pm 0.08$ \\
$\mathbf{4 m}$ & $5.60 \pm 0.6$ \\
$\mathbf{4 n}$ & $12.2 \pm 0.05$ \\
$\mathbf{4 0}$ & $15.1 \pm 0.8$ \\
$\mathbf{4 r}$ & $(39)^{\mathrm{a}}$ \\
Thiourea (standard) & $22.3 \pm 1.2$ \\
\hline
\end{tabular}

${ }^{a} \%$ age inhibition was evaluated using inhibitor at a concentration of $100 \mu \mathrm{M}$.

TABLe 2: Antibacterial activity of 1,3,4-oxadiazoles derivatives by micro dilution method ( $\mathrm{MIC}^{\mathrm{a}}$ values $\mu \mathrm{g} / \mathrm{mL}$ ).

\begin{tabular}{lcccc}
\hline Compound & E. coli & B. subtilus & S. aureus & S. flexneri \\
\hline 4a & 0.313 & 0.156 & 1.25 & 0.313 \\
4b & 0.625 & 0.313 & 0.156 & 0.313 \\
4c & 2.50 & 0.156 & 0.625 & 0.156 \\
$\mathbf{4 e}$ & 0.156 & 0.625 & 0.313 & 0.313 \\
$\mathbf{4 f}$ & 0.313 & 0.156 & 0.156 & 1.25 \\
$\mathbf{4 g}$ & 0.156 & 0.625 & 2.50 & 0.313 \\
$\mathbf{4 h}$ & 1.25 & 0.156 & 0.625 & 0.156 \\
$\mathbf{4 i}$ & 0.156 & 0.625 & 0.313 & 0.313 \\
$\mathbf{4 j}$ & 0.313 & 1.25 & 0.313 & 0.156 \\
$\mathbf{4 k}$ & 0.156 & 0.313 & 0.156 & 0.156 \\
$\mathbf{4 l}$ & 0.313 & 2.50 & 0.625 & 0.156 \\
$\mathbf{4 m}$ & 0.625 & 0.156 & 1.25 & 0.313 \\
$\mathbf{4 n}$ & 0.625 & 0.156 & 0.156 & 0.156 \\
$\mathbf{4 0}$ & 0.313 & 0.625 & 2.50 & 0.156 \\
$\mathbf{4 r}$ & 1.25 & 0.313 & 0.156 & 0.313 \\
Ciprofloxacin & 0.156 & 0.625 & 0.156 & 0.31 \\
\hline
\end{tabular}

${ }^{a}$ Values are the average of three reading.

compounds bear electron donating methoxy groups at oand p-positions and were more active than compounds $4 \mathrm{n}$ and $4 \mathrm{o}$ having electron donating groups at m-position. Compound $\mathbf{4} \mathrm{c}$ having bromo substitution at para position and compound $4 \mathbf{e}$ having chloro substitution at meta and para position showed slightly less activity than methoxy substituted 1,3,4-oxadiazoles. Compound $\mathbf{4 b}$ and standard thiourea had nearly same activity against urease. The exceptions were compounds $\mathbf{4 h}$ and $\mathbf{4 r}$ having 2,4-dichlorobenzyl group exhibited weak inhibitory activities. 


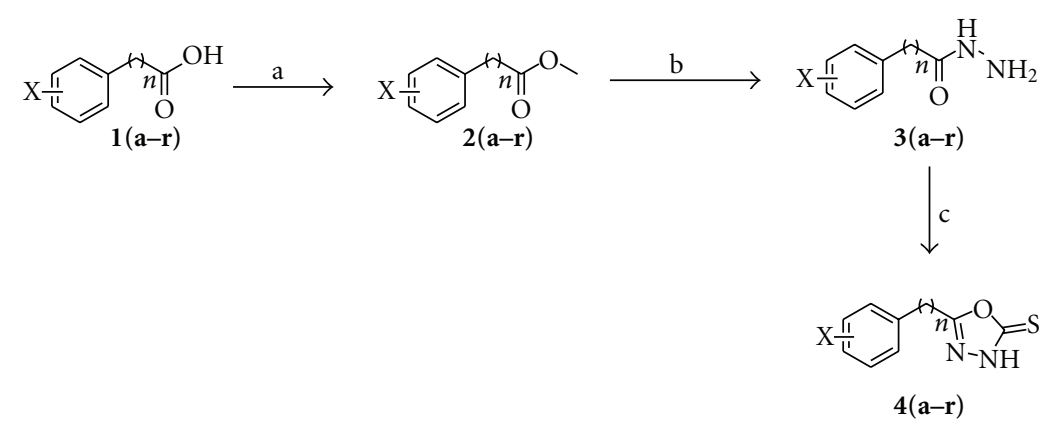

\begin{tabular}{|c|c|c|c|c|c|}
\hline Compound & $\mathrm{X}$ & $n$ & Compound & $\mathrm{X}$ & $n$ \\
\hline $4 a$ & 2,3,4-tri $\left(\mathrm{OCH}_{3}\right)$ & 0 & $4 j$ & $4-\mathrm{Cl}$ & 1 \\
\hline $4 b$ & Indole-2-yl & 0 & $4 k$ & $2-\mathrm{Cl}$ & 1 \\
\hline $4 c$ & $4-\mathrm{Br}$ & 1 & 41 & $4-\mathrm{OCH}_{3}$ & 1 \\
\hline $4 d$ & $4-\mathrm{CH}_{3}$ & 1 & $4 \mathrm{~m}$ & $2-\mathrm{OCH}_{3}$ & 1 \\
\hline $4 e$ & 3,4-diCl & 1 & $4 n$ & $3-\mathrm{OCH}_{3}$ & 1 \\
\hline $4 \mathrm{f}$ & $2-\mathrm{F}$ & 1 & 40 & $3-\mathrm{OCH}_{3}$ & 2 \\
\hline $4 g$ & $4-\mathrm{OCH}_{3}$ & 2 & $4 p$ & Pyridine-3-yl & 0 \\
\hline $4 \mathrm{~h}$ & 2,4-diCl & 1 & $4 q$ & 2,6-diCl & 1 \\
\hline $4 i$ & $2-\mathrm{OCH}_{3}$ & 2 & $4 r$ & 2-F, 4-Cl & 0 \\
\hline
\end{tabular}

Scheme 1: Synthesis of oxadiazoles (4a-r). Reagents and conditions: (a) $\mathrm{H}_{2} \mathrm{SO}_{4}$ (conc.), methanol, reflux, $8-12 \mathrm{~h}$; (b) $\mathrm{NH}_{2} \mathrm{NH}_{2} \cdot \mathrm{H}_{2} \mathrm{O}(80 \%)$, ethanol, reflux, 8-12 h; (c) (1) $\mathrm{CS}_{2} / \mathrm{KOH}$, ethanol, reflux, $12 \mathrm{~h}$; (2) $\mathrm{HCl} \mathrm{pH} \mathrm{5-6.}$

It is clear from the SAR of synthesized derivatives of 1,3,4-oxadiazoles that 2 and 4 positions of terminal benzene ring is favorable site for high activity. However, a single parameter is insufficient to explain the pattern and mechanism by which 1,3,4-oxadiazoles exhibited the urease inhibition.

3.3. Antibacterial Activity. The synthesized derivatives were screened for antibacterial activity against Gram-positive bacteria (Staphylococcus aureus, Bacillus subtilis) and Gramnegative bacteria (Escherichia coli, and Shigella flexneri). The results of antibacterial activity of 1,3,4-oxadiazoles are presented in Table 2. Ciprofloxacin was used as standard and the minimum inhibitory concentrations (MICs) were determined in vitro by using serial tube dilution method.

Some of the synthesized derivatives were found to have more potent antibacterial activity then standard ciprofloxacin against the tested strains. In particular, derivatives $4 \mathbf{e}, \mathbf{4 g}, \mathbf{4} \mathbf{i}, \mathbf{4 k}$, and $\mathbf{4 r}$ which possess a 3,4dichlorobenzyl, 4-methoxyphenethyl, 2,4-dichlorobenzyl, 2methoxy, 2-chloro and 2-F, 4-Cl phenyl groups respectively, on the 1,3,4-oxadiazole ring, were found to have potent activities (MIC: $0.156 \mu \mathrm{g} / \mathrm{mL}$ ) against $E$. coli and were equipotent in vitro as standard drug ciprofloxacin (MIC: $0.156 \mu \mathrm{g} / \mathrm{mL}$ ). Compounds $\mathbf{4 c}, \mathbf{4 h}$, and $\mathbf{4 r}$ were considerably less active. The compounds demonstrated significant antibacterial activity against $B$. subtilus. The derivatives $4 \mathrm{a}, 4 \mathrm{c}, 4 \mathrm{f}, 4 \mathrm{~h}, \mathbf{4 m}$, and $4 \mathbf{n}$ exhibited 4 -fold activity. The exceptions were $\mathbf{4 j}$ and 41 with para chloro and para methoxy group, respectively. For bacterial strain S. Aureus, compounds $4 \mathbf{b}, 4 \mathbf{f}, 4 \mathbf{k}, 4 \mathbf{n}$, and $4 \mathbf{r}$ showed equipotent activity as compared to standard ciprofloxacin. These compounds were obtained by the substitution of halogen at various positions of benzene ring. Compounds $4 \mathrm{c}, 4 \mathrm{~h}, \mathbf{4 j}, \mathbf{4 k}, 4 \mathbf{l}, \mathbf{4 n}$, and $4 \mathrm{o}$ showed two- fold activities against $S$. flexneri strain. Compounds $4 \mathbf{a}, 4 \mathbf{b}, 4 \mathbf{e}$, $4 \mathrm{~g}, 4 \mathrm{i}, 4 \mathrm{~m}$, and $4 \mathrm{r}$ showed equipotent activity. However, $4 \mathrm{f}$ showed no activity as it has floro group at ortho position. The high potency of discussed analogues may be attributed to the $\mathrm{F}, \mathrm{Cl}$ and $\mathrm{OCH}_{3}$ at 2- or 4-positions which rationally correlates with SAR of urease inhibition activity.

3.4. Antioxidant Studies. The 2,2-diphenyl-1-picryl-hydrazyl (DPPH) radical scavenging activity assessment is a standard assay in antioxidant activity measurements. For comparison purpose, the well-defined antioxidant propyl gallate and 3tert-Butyl-4-hydroxyanisole were used in assay as positive control. The antioxidant activities of the compounds are shown in Table 3.

The most interesting activity was observed in $4 \mathbf{r}$ having 2F, 4-Cl phenyl groups which showed four-fold DPPH radical scavenging activity as compared to standard propyl gallate. Two other derivatives $\mathbf{4 k}$ and $\mathbf{4} \mathbf{c}$ were also more effective than the propyl gallate having 2-chloro and 4-bromo substitutions on benzene ring next to parent core. Equipotent radical scavenging activity was found in $4 \mathbf{i}$ having 2-methoxy phenyl group. Among methoxy substituted phenyl rings, the derivatives $\mathbf{4 m}, \mathbf{4 o}, \mathbf{4 g}$, and $\mathbf{4 n}$ exhibited good potentials having $\mathrm{IC}_{50}$ values $42.74 \mu \mathrm{M}$ to $60.28 \mu \mathrm{M}$. Similarly, $4 \mathrm{f}, \mathbf{4 j}, \mathbf{4 k}$, and $4 \mathbf{e}$ which have halogen substituted phenyl rings showed potency in the range of $46.63 \mu \mathrm{M}$ to $58.97 \mu \mathrm{M}$. 4a having trimethoxy phenyl ring and $\mathbf{4 b}$ were relatively less active derivatives of the series. 
TABLE 3: DPPH radical scavenging activity of 1,3,4-oxadiazoles derivatives.

\begin{tabular}{lc}
\hline Compounds & $\mathrm{IC}_{50}(\mu \mathrm{M})$ \\
\hline $\mathbf{4 a}$ & $122.6 \pm 5.1$ \\
$\mathbf{4 b}$ & $107.2 \pm 3.4$ \\
$\mathbf{4 c}$ & $37.98 \pm 4.1$ \\
$\mathbf{4 e}$ & $58.97 \pm 6.3$ \\
$\mathbf{4 f}$ & $46.63 \pm 4.6$ \\
$\mathbf{4 g}$ & $50.78 \pm 2.1$ \\
$\mathbf{4 h}$ & $57.82 \pm 1.8$ \\
$\mathbf{4 i}$ & $40.20 \pm 3.3$ \\
$\mathbf{4 j}$ & $51.61 \pm 2.1$ \\
$\mathbf{4 k}$ & $34.40 \pm 3.2$ \\
$\mathbf{4 l}$ & $88.18 \pm 4.1$ \\
$\mathbf{4 m}$ & $42.74 \pm 3.7$ \\
$\mathbf{4 n}$ & $60.28 \pm 4.3$ \\
$\mathbf{4 o}$ & $43.59 \pm 3.1$ \\
$\mathbf{4 r}$ & $10.83 \pm 0.2$ \\
Propyl gallate & $40.80 \pm 1.2$ \\
3-tert-Butyl-4-hydroxyanisole & $28.20 \pm 1.1$ \\
\hline
\end{tabular}

TABle 4: FlexX docking scores and ranks for the docked compounds.

\begin{tabular}{lcc}
\hline Compound & Rank & Score \\
\hline $\mathbf{4 a}$ & 1 & -14.09 \\
$\mathbf{4 b}$ & 1 & -19.35 \\
$\mathbf{4 c}$ & 1 & -16.55 \\
$\mathbf{4 d}$ & 1 & -11.09 \\
$\mathbf{4 e}$ & 1 & -13.05 \\
$\mathbf{4 f}$ & 1 & -16.96 \\
$\mathbf{4 g}$ & 1 & -20.95 \\
$\mathbf{4 h}$ & 1 & -14.64 \\
$\mathbf{4 i}$ & 1 & -12.46 \\
$\mathbf{4 j}$ & 1 & -14.63 \\
$\mathbf{4 k}$ & 1 & -13.03 \\
$\mathbf{4 l}$ & 1 & -23.49 \\
$\mathbf{4 m}$ & 3 & -13.61 \\
$\mathbf{4 n}$ & 1 & -26.26 \\
$\mathbf{4 o}$ & 1 & -18.46 \\
$\mathbf{4 p}$ & 1 & -13.35 \\
$\mathbf{4 q}$ & 1 & -13.35 \\
$\mathbf{4 r}$ & 1 & -26.84 \\
\hline
\end{tabular}

3.5. Molecular Docking Studies. The compounds were studied by docking them into the crystal structure of Jack bean urease to observe the common behavior of interaction of these compounds with the enzyme. The top 18 predicted docked solutions (conformations) generated by FlexX were retained for analyzing the binding modes of the compounds. It was observed that all of the compounds have a similar binding mode in the first out of 18 ranked predictions. The docking scores varied from -11.09 to -26.84 , which are given in Table 4. The docking results showed that all of these

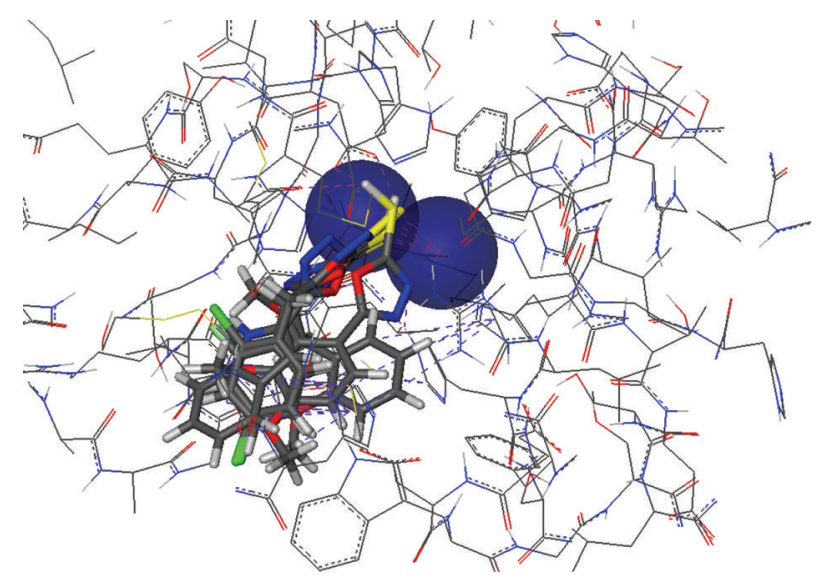

Figure 1: Predicted conformations of the docked compounds inside the binding pocket of Jack bean urease. The large blue spheres indicate the metal pharmacophores around the two nickels $\left(\mathrm{Ni}^{+2}\right)$ which shows that the metal atoms can interact in all directions. The dotted lines indicate various types of interactions of the compounds atoms with the active site residues including hydrogen bonding and aromatic interactions.

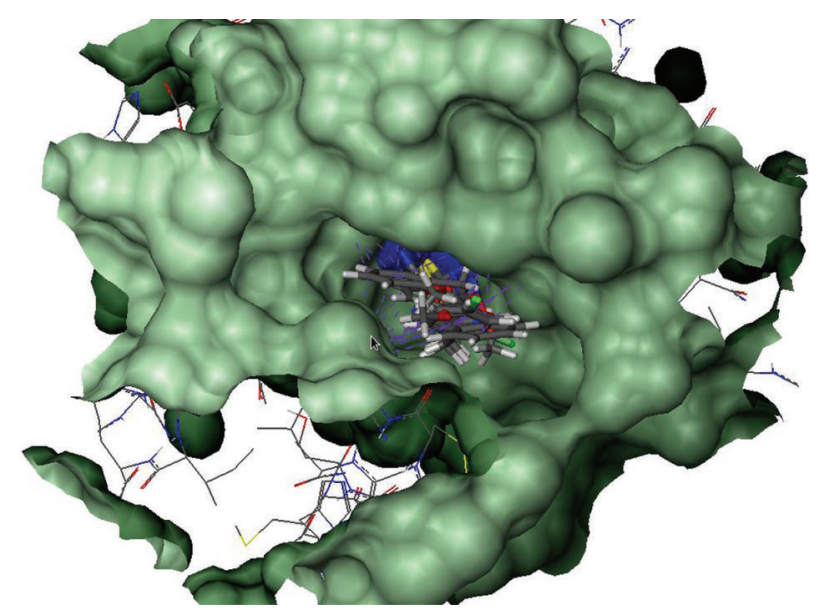

FIGURE 2: Surface representation of the active site pocket of the Jack bean urease with the bound ligands shown inside the pocket in CPK model. The wide opening of the binding site pocket allows the compounds to adopt flexible conformations in this area.

compounds interact with the bi-nickel center of the enzyme. The S group of the compounds tends to interact with the two nickel atoms (Figure 1) while the aromatic moieties of the compounds adopt flexible conformations in the large hydrophobic opening of the active site pocket (Figure 2). With a special pharmacophore module, FlexX-Pharm [27], FlexX offers an automated pharmacophore query building for the metal atoms. The two Nickel atoms were chosen to be used as essential part of the pharmacophoric constraints for filtering the predicted docking solutions. It was observed that all compounds bind in the same mode fulfilling that metal pharmcophoric constraints. The aromatic rings of the compounds make similar stack of interactions with HIS492, HIS593, ARG439, and ALA440 residues which form 


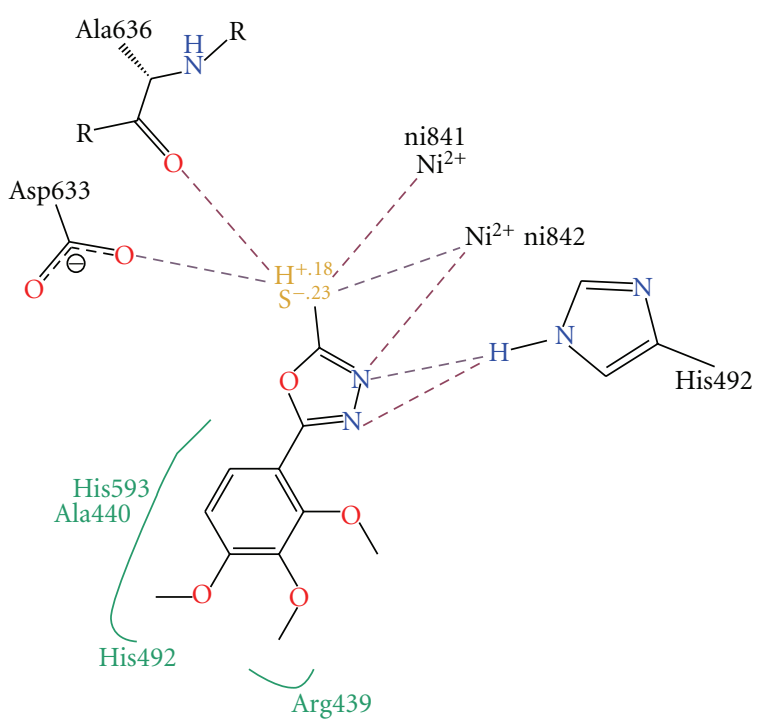

FIGURE 3: Interaction diagram of the docked conformation of compound $4 \mathbf{a}$ with the active site residues of the enzyme. The dotted lines show the interactions between the compound and residues atoms.

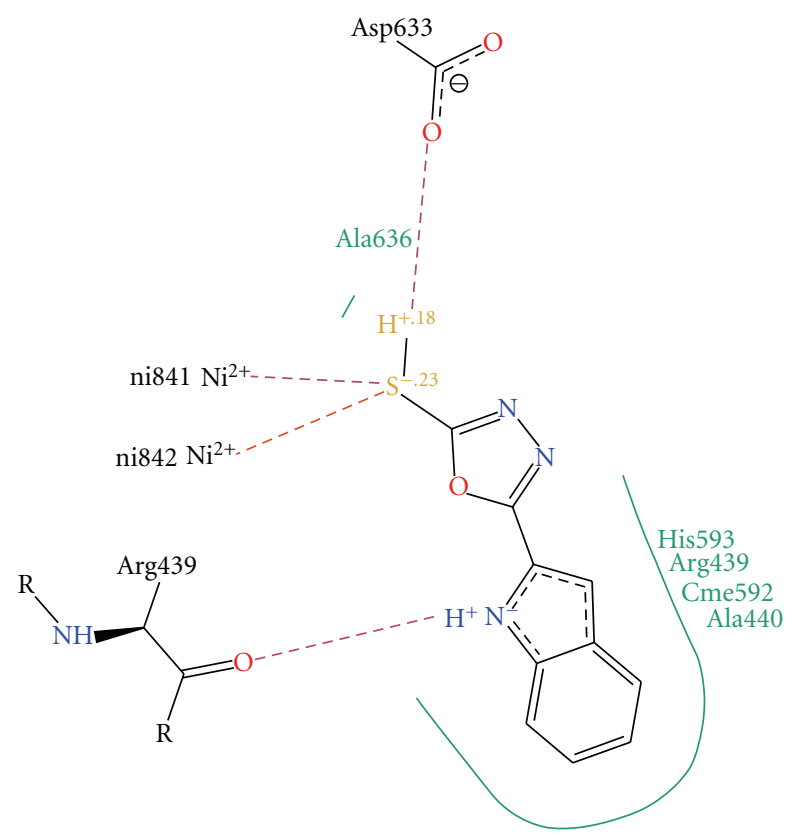

Figure 4: Interaction diagram of the docked conformation of compound $\mathbf{4 b}$ with the active site residues of the enzyme. The dotted lines show the interactions between the compound and residues atoms.

a hydrophobic cavity in the opening of the active site pocket and allow greater flexibility to the compounds to adopt different conformations in that area. The aromatic interactions with histidine ring of HIS593 on one side and ARG439 and ALA440 on other side in the hydrophobic pocket is common to the majority of predicted binding poses of the compounds. The docked conformations of the compounds $\mathbf{4 a}$ and $\mathbf{4 b}$ are shown in Figures 3 and 4 , respectively.

\section{Acknowledgment}

This work was financially supported by the Higher Education Commission (HEC), Pakistan, under the National Research Support Program for Universities and German-Pakistani Research Collaboration Program to J. Iqbal.

\section{References}

[1] H. L. T. Mobley and R. P. Hausinger, "Microbial ureases: significance, regulation, and molecular characterization," Microbiological Reviews, vol. 53, no. 1, pp. 85-108, 1989.

[2] H. L. T. Mobley, M. D. Island, and R. P. Hausinger, "Molecular biology of microbial ureases," Microbiological Reviews, vol. 59, no. 3, pp. 451-480, 1995.

[3] S. Vassiliou, A. Grabowiecka, P. Kosikowska, A. Yiotakis, P. Kafarski, and L. Berlicki, "Design, synthesis, and evaluation of novel organophosphorus inhibitors of bacterial ureases," Journal of Medicinal Chemistry, vol. 51, no. 18, pp. 5736-5744, 2008.

[4] N. C. Ha, S. T. Oh, J. Y. Sung et al., "Supramolecular assembly and acid resistance of Helicobacter pylori urease," Nature Structural \& Molecular Biology, vol. 8, no. 6, pp. 505-509, 2001.

[5] E. Jabri, M. B. Carr, R. P. Hausinger, and P. A. Karplus, "The crystal structure of urease from Klebsiella aerogenes," Science, vol. 268, no. 5213, pp. 998-1004, 1995.

[6] S. Benini, W. R. Rypniewski, K. S. Wilson, S. Miletti, S. Ciurli, and S. Mangani, "A new proposal for urease mechanism based on the crystal structures of the native and inhibited enzyme from Bacillus pasteurii: why urea hydrolysis costs two nickels," Structure, vol. 7, no. 2, pp. 205-216, 1999.

[7] C. Gripenberg-Lerche, L. Zhang, P. Ahtonen, P. Toivanen, and M. Skurnik, "Construction of urease-negative mutants of Yersinia enterocolitica serotypes O:3 and O:8: role of urease in virulence and arthritogenicity," Infection and Immunity, vol. 68, no. 2, pp. 942-947, 2000.

[8] X. Li and H. L. T. Mobley, "Vaccines for Proteus mirabilis in urinary tract infection," International Journal of Antimicrobial Agents, vol. 19, no. 6, pp. 461-465, 2002.

[9] Z. Amtul, A. U. Rahman, R. A. Siddiqui, and M. I. Choudhary, "Chemistry and mechanism of urease inhibition," Current Medicinal Chemistry, vol. 9, no. 14, pp. 1323-1348, 2002.

[10] S. Uesato, Y. Hashimoto, M. Nishino, Y. Nagaoka, and H. Kuwajima, "N-substituted hydroxyureas as urease inhibitors," Chemical and Pharmaceutical Bulletin, vol. 50, no. 9, pp. 12801282, 2002.

[11] S. Odake, T. Morikawa, M. Tsuchiya, L. Imamura, and K. Kobashi, "Inhibition of Helicobacter pylori urease activity by hydroxamic acid derivatives," Biological and Pharmaceutical Bulletin, vol. 17, no. 10, pp. 1329-1332, 1994.

[12] W. S. Faraci, B. V. Yang, D. O’Rourke, and R. W. Spencer, "Inhibition of Helicobacter pylori urease by phenyl phosphorodiamidates: mechanism of action," Bioorganic and Medicinal Chemistry, vol. 3, no. 5, pp. 605-610, 1995.

[13] A. J. Pope, C. D. N. Toseland, B. Rushant, S. Richardson, M. Mcvey, and J. Hills, "Effect of potent urease inhibitor, fluorofamide, on Helicobacter sp. in vivo and in vitro," Digestive Diseases and Sciences, vol. 43, no. 1, pp. 109-119, 1998.

[14] J. B. Park, L. Imamura, and K. Kobashi, "Kinectic studies of Helicobacter pylori urease inhibition by a novel proton pump 
inhibitor, rabeprazole," Biological and Pharmaceutical Bulletin, vol. 19, no. 2, pp. 182-187, 1996.

[15] K. Nagata, H. Satoh, T. Iwahi, T. Shimoyama, and T. Tamura, "Potent inhibitory action of the gastric proton pump inhibitor lansoprazole against urease activity of Helicobacter pylori: unique action selective for $H$. pylori cells," Antimicrobial Agents and Chemotherapy, vol. 37, no. 4, pp. 769-774, 1993.

[16] T. C. Kuhler, J. Fryklund, N. A. Bergman, J. Weilitz, A. Lee, and H. Larsson, "Structure-activity relationship of omeprazole and analogues as Helicobacter pylori urease inhibitors," Journal of Medicinal Chemistry, vol. 38, no. 25, pp. 4906-4916, 1995.

[17] L. G. Bundy and J. M. Bremner, "Effects of substituted pbenzoquinones on urease activity in soils," Soil Biology and Biochemistry, vol. 5, no. 6, pp. 847-853, 1973.

[18] M. J. Todd and R. P. Hausinger, "Competitive inhibitors of Klebsiella aerogenes urease. Mechanisms of interaction with the nickel active site," The Journal of Biological Chemistry, vol. 264, no. 27, pp. 15835-15842, 1989.

[19] H. Kogen, K. Tago, M. Arai, E. Minami, K. Masuda, and T. Akiyama, "A highly stereoselective synthesis of plaunotol and its thiourea derivatives as potent antibacterial agents against Helicobacter pylori," Bioorganic and Medicinal Chemistry Letters, vol. 9, no. 10, pp. 1347-1350, 1999.

[20] M. A. Aslam, S. U. Mahmood, M. Shahid et al., "Synthesis, biological assay in vitro and molecular docking studies of new Schiff base derivatives as potential urease inhibitors," European Journal of Medicinal Chemistry, vol. 46, no. 11, pp. 5473-5479, 2011.

[21] O.-U.-R. Abid, T. M. Babar, F. I. Ali et al., "Identification of novel urease inhibitors by high-throughput virtual and in vitro screening," ACS Medicinal Chemistry Letters, vol. 1, no. 4, pp. 145-149, 2010.

[22] M. Moise, V. Sunel, L. Profire, M. Popa, J. Desbrieres, and C. Peptu, "Synthesis and biological activity of some new 1,3,4-thiadiazole and 1,2,4-triazole compounds containing a phenylalanine moiety," Molecules, vol. 14, no. 7, pp. 26212631, 2009.

[23] W. Shi, X. Qian, R. Zhang, and G. Song, "Synthesis and quantitative structure-activity relationships of new 2,5-disubstituted-1,3,4-oxadiazoles," Journal of Agricultural and Food Chemistry, vol. 49, no. 1, pp. 124-130, 2001.

[24] M. Amir and K. Shikha, "Synthesis and anti-inflammatory, analgesic, ulcerogenic and lipid peroxidation activities of some new 2-[(2,6-dichloroanilino) phenyl]acetic acid derivatives," European Journal of Medicinal Chemistry, vol. 39, no. 6, pp. 535-545, 2004.

[25] M. W. Weatherfourn, "PhenoI-hypochlorite reaction for determination of ammonia," Analytical Chemistry, vol. 39, no. 8, pp. 971-974, 1967.

[26] M. Rarey, B. Kramer, T. Lengauer, and G. Klebe, "A fast flexible docking method using an incremental construction algorithm," Journal of Molecular Biology, vol. 261, no. 3, pp. 470-489, 1996.

[27] S. A. Hindle, M. Rarey, C. Buning, and T. Lengauer, "Flexible docking under pharmacophore type constraints," Journal of Computer-Aided Molecular Design, vol. 16, no. 2, pp. 129-149, 2002. 

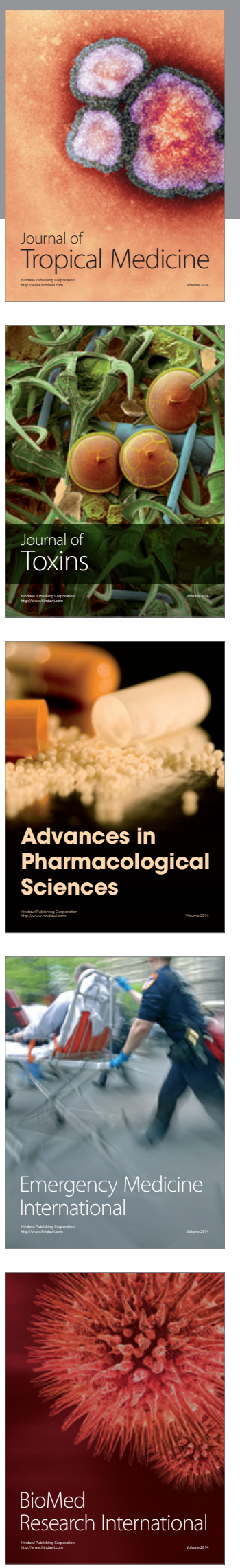
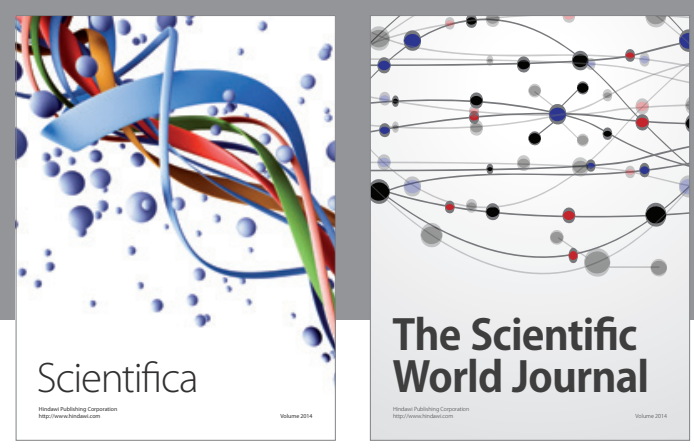

The Scientific World Journal
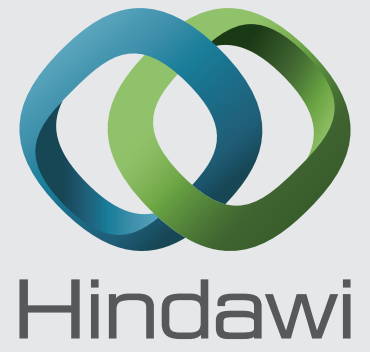

Submit your manuscripts at

http://www.hindawi.com
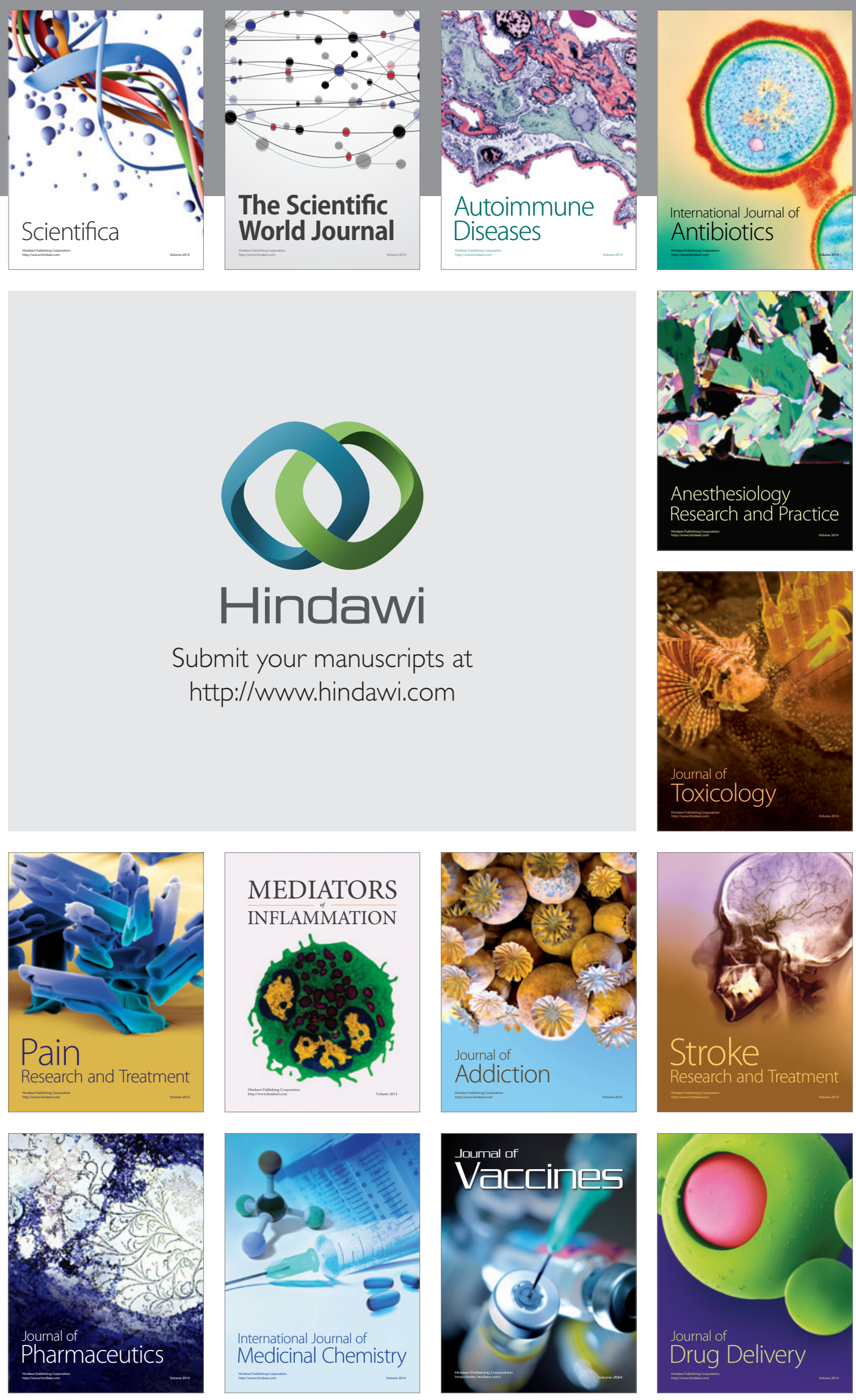